\title{
How VIPs and IT-professionals behave in Russian. The use of loan abbreviations in Russian analytical composites
}

\author{
Elizaveta Tarasova \\ IPU New Zealand Tertiary Institute \\ etarasova@ipu.ac.nz
}

\begin{abstract}
The current research is focused on the English $\mathrm{N}+\mathrm{N}$ pattern, which is widely reported to have been borrowed into Russian under the influence of numerous compounds that have entered Russian recently. The data used for analysis include loanwords with $\mathrm{N}+\mathrm{N}$ structure (e.g., бизнесмен [businessman], арт-магазин [art shop]), a considerable proportion of which are units with loan abbreviations in the leftmost (modifying) position (e.g., пиар-директор [pi'ar direktor] 'PR director', ВИП-места [vipmesta] 'VIP seats'). The paper looks at the general principles of assimilation using Krysin's (1975) framework to understand whether it is possible to talk about changes in the Russian morphology under the influence of lexical borrowing. The analysis of the Russian $\mathrm{N}+\mathrm{N}$ data to date allows for two explanations for the growing productivity of the analytical pattern. One of these is the revival of the superficially similar Russian $\mathrm{N}+\mathrm{N}$ morphological pattern which had fallen out of productivity. The other explanation concerns the necessity of preserving the meaning of the loan and its conceptual value, which may otherwise be affected in the process of derivational assimilation.
\end{abstract}

Keywords: assimilation, $\mathrm{N}+\mathrm{N}$ compounds, Russian $\mathrm{N}+\mathrm{N}$ composites, derivation, loanwords, loan abbreviations

\section{Introduction}

A continuous interest in the research devoted to the issue of changes in European and world languages under the influence of English has been growing. The topics of 
investigation range from the patterns of assimilation of loanwords and changes in the lexis (Haspelmath and Tadmor, 2009; Haugen, 1950; Hyman, 1970) to the changes in morphological processes (Panov, 1999; Ryazanova-Clarke and Wade, 1999; Dimitrova et al, 2011; Gazda, 2008; Rochtchina, 2012; Panov, 1999) and even syntactic structures (Nagano and Shimada, 2016). One of the issues in this area is the tendency to analytism in word-formation processes, which is attributed to the influence of (American) English through the number of borrowings registered in inflectionally rich languages.

The overarching question that this investigation attempts to contribute to is compound genesis in Russian, and this paper aims to present some insights on how compounds that use the English $\mathrm{N}+\mathrm{N}$ pattern assimilate and/or develop in Russian. Analytical N+N compounds like бизнес-план [biznes-plan] 'business plan' and рокмузыка [rok-muzyka] 'rock music' are viewed as items of lexical borrowing, and they are often reported to impact Russian derivational morphology, shifting it towards analytism (Dyakov, 2001; Rochtchina, 2012; Ryazanova-Clarke and Wade, 1999, to name just a few). Similar claims are made about other Slavic languages, e.g. Czech (Gazda, 2008), Bulgarian (Bagasheva, 2016), Polish (Sztencel, 2009), and others. This research looks at the matters of assimilation of English $\mathrm{N}+\mathrm{N}$ compounds and the extension of the analytical $\mathrm{N}+\mathrm{N}$ pattern in such an inflectionally rich language as Russian. For the reasons of space, the paper focuses mainly on Russian $\mathrm{N}+\mathrm{N}$ compounds in which the first element is represented by a loan abbreviation (LA) that functions as a word.

This investigation is part of a corpus-based project in which a database of 2,000 Russian analytical composites was collected and analysed. The types of Russian composites were picked from the Russian National Corpus (henceforth - the RNC), as well as from the current Russian printed media; e.g., Известия, Экономист, Аргументы и факты, etc. The choice of the resources for data collection was determined by the necessity of looking at the occurrences of Russian composites in nonspecific contexts. This research looks at the data from a synchronic perspective for two reasons. Firstly, the frequency-based evidence is not as important for this research as the analysis of various types of LA+N compounds; and secondly, the RNC is relatively small and cannot be used as a reference point at this stage. However, looking at the matters diachronically would provide a deeper understanding of the development of this morphological pattern.

The analysis of loans and stages of their assimilation in the language uses the criteria offered by Krysin (1975) to decide whether a loan is fully or partially assimilated in the target language. The reason for choosing Krysin's set of criteria over others - e.g., Haugen's (1950) 1 - is that this set answers the requirements of this study because it was developed for the analysis of loans in Russian and covers the points (shown below) relevant to this investigation. Another reason for choosing this framework for the analysis is dictated by the aim of the paper, which is to look at the overall trend in the morphology of modern Russian rather than assign the analysed compound types to certain categories. Besides, as justly noted by Gómez Capuz (1997: 82 ), most of the proposed typologies and classifications were created to match mainly 
Western languages. As a result, they may lack full validity since the discrete categories they operate with cannot account for all the factors involved in a given socio-linguistic situation. Finally, Krysin's criteria allow for focusing on the process of assimilation of one and the same borrowed word on different levels (phonological, orthographic, semantic, grammatical).

The paper starts with the general description of characteristics of $\mathrm{N}+\mathrm{N}$ compounds in English and Russian, and demonstrates the similarities and differences between the patterns of formation to explain how the English $\mathrm{N}+\mathrm{N}$ pattern is utilised as a special way of assimilating novel loans in general, with special attention to assimilation of LAs.

\section{English $\mathbf{N}+\mathbf{N}$ compounds and compounding in Russian}

$\mathrm{N}+\mathrm{N}$ compounds in English represent an interesting field of research. The issue of the position of $\mathrm{N}+\mathrm{N}$ compounds in English grammar, as well as other topics, including classification of compounds, their formal structure and semantic characteristics, are rather controversial. For the purposes of this paper, which is not focused on the questions associated with $\mathrm{N}+\mathrm{N}$ compounding in English, the generic definition that a compound is a new lexeme formed by adjoining two or more lexemes (Bauer, 2003: 40) is accepted. The term "N+N compound" is used to refer to English noun-noun sequences that satisfy the above definition.

Overall, the process of combining two nouns in order to create a new concept is believed to be typical of analytical languages. However, the results of the study by Stekauer et al. (2008) suggest that compounding is widely spread across languages, even though the means for creating nominal compounds may differ. Hence, it is interesting to see how similar/different Russian compounds are from English N+Ns.

\subsection{Russian $\mathrm{N}+\mathrm{N}$ compounds}

Shvedova (1980: 139) refers to the word-formation pattern of combinations with the $\mathrm{N}+\mathrm{N}$ structure as 'agglutination'/'pure compounding', that is a type of word formation where the base component is equivalent to a full word and the preceding component is represented by a root morpheme. The meaning of the new word is described as the sum of the meanings of the components. The first component is believed to be a root morpheme (rather than a word), and the whole construction is a complex word. ${ }^{2}$

Pure compounding is one of the productive word-formation processes in Russian, in which two noun roots/bases are normally connected ("glued" to each other) by an interfix -о-, as in хлебозавод[khlebozavod] 'bread-making plant' or -e-, as in птицефабрика [ptitsefabrika] 'poultry factory'. Compounds that employ zero interfix are usually characterised by the neuter gender of the first element; e.g., радиостанция [radiostantsiya] 'radio station'. Neuter gender nouns in Russian end in either $-e$ or $-o$; therefore, it is not always clear whether the final vowel of such nouns belongs to the first element of the compound or whether this vowel is an interfix. Units formed by the 
process of pure compounding also include cases which have formal characteristics of English $\mathrm{N}+\mathrm{Ns}$, whereby the first element is represented by a free root morpheme that can be used as a noun lexeme (N1). The use of the hyphen or one-word spelling in such sequences is often considered as the main criterion for identifying whether we deal with a complex word rather than a phrase (Shvedova, 1980). ${ }^{3}$ However, this type is unproductive and the formations are limited to very few Russian words which can be used in N1 position, e.g. u̧aps, as in цุapь-nушка [tsar'-pushka]'king cannon'; жар, as in жар-птииа [zhar-ptitsa] 'fire bird'"; горе, as in горе-человек [gore-chelovek] 'unfortunate person'; and чудо, as in чудо-печь [chudo-pech'] 'wonder oven' (Shvedova, 1980).

The important characteristic of such sequences which allows for drawing a parallel between Russian complexes and English $\mathrm{N}+\mathrm{N}$ compounds is the lack of inflectional markers on the leftmost element (e.g. for case and number) when it is required by syntax. This means that N1 in such units is used analytically, which makes them structurally similar to English N+Ns.

Когда после сорокалетнего перерыва открыли Кремль для всеобщего обозрения, я, ..., в месте со своими друзьями кинулся скорей посмотреть царь-пушку([tsar'-pushk.u] 'tsar'cannon:SuffAcc') и царь-колокол.

(When, after a forty-year break, the Kremlin was opened for public viewing, I, ..., together with my friends rushed to see the tsar cannon and the tsar bell.)

Я давно собирался посмотреть на гнездышко такой жар-nтицы ～([zhar-ptits.y] ' 'firebird:SuffGen'), как Вы, - шутя сказал Иван Павлович.

(I've been going to look at the nest of a firebird like you for a while - Ivan Pavlovich said jokingly.)

The examples above demonstrate the analytical use of the first component in the Russian $\mathrm{N}+\mathrm{N}$ compounds, where the leftmost component has a zero ending, and the obligatory case marking is assigned to the head. Hence, it is possible to suggest that one of the compound formation processes in Russian employs the pattern which bears formal similarity to the analytical English $\mathrm{N}+\mathrm{N}$ compounds.

The limited number of analytical $\mathrm{N}+\mathrm{N}$ compounds in Russian can be explained by the fact that being a highly inflected language, Russian allows for the formation of adjectives from practically any noun, verb or other adjective (Townsend, 1968; Corbett, 2004). Consequently, indigenous Russian words and well-assimilated loans may serve as derivational bases for the formation of adjectives. As Corbett (2004: 201) notes, Russian employs a derived adjective + noun sequence книжныймагазин [knizh.nyi magazin] 'bookshop', while many European languages use an $\mathrm{N}+\mathrm{N}$ compound. Therefore, there is no pragmatic need for the use of nouns for modification, and availability of adjectives makes modifying a noun using another noun redundant.

\subsection{Borrowed $\mathrm{N}+\mathrm{Ns}$ in Russian}


In recent years, the number of items that use the English $\mathrm{N}+\mathrm{N}$ pattern has increased dramatically, and a considerable amount of research on this issue has started to appear. The term that is often used for these constructions is "analytical composites" (Karaulov, 1998: 443) because the modifying element in composite structures does not acquire inflections to reflect the syntactic function, part of speech and/or case. The increase in these units is attributed to the influence of borrowed English $\mathrm{N}+\mathrm{Ns}$, in which the first element bears no morphological markers to allow for defining its morphological category. Russian $\mathrm{N}+\mathrm{N}$ composites use loanwords in the modifier position, but some of them have been created in Russian rather than borrowed from English (e.g. бизнес-леди [biznes-ledy] 'business woman'). This gives rise to the suggestion that borrowing English compounds into Russian may have also triggered borrowing the wordformation pattern. At the same time, it may also be the case that assimilation of the $\mathrm{N}+\mathrm{N}$ compounds could be viewed as a catalyst for bringing back to life the old uapbпушка [tsar'-pushka]'king cannon' pattern, which has fallen out of productivity.

The paper analyses Russian analytical $\mathrm{N}+\mathrm{N}$ composites (specially focusing on the use of LAs in the modifying position) to see how borrowed units with this structure develop in Russian and whether it is justified to speak about borrowing of the morphological pattern under the influence of lexical borrowing. Before moving to the analysis of the Russian $\mathrm{N}+\mathrm{Ns}$, it is important to outline how the principles of assimilation work in Russian.

\section{Assimilation of loans in Russian}

The analysis of loanwords needs to consider the stages a loan undergoes in the process of assimilation in the new linguistic environment. The chosen framework (Krysin, 1975) addresses the following criteria:

1. Categorising the graphic-phonetic representation of a loan by means of the spelling system of the recipient language (phonological and orthographic assimilation);

2. Referring the borrowed lexeme to a certain grammatical class and category as prescribed by the grammar of the recipient language (grammatical assimilation);

3. Confirming semantic independence of the borrowed word when a loan is not a full synonym of some indigenous word of the recipient language or an earlier borrowing from elsewhere that is now accepted as part of the recipient language (semantic assimilation);

4. Identifying the derivational productivity of the borrowed word (derivational assimilation).

Below is a brief description of different kinds of assimilation of loans in Russian. Derivational assimilation is discussed in more detail for reasons that will be explained later in the paper. 


\subsection{Phonological assimilation}

Once a borrowed word enters a language, it changes its phonological form in accordance with the restrictions on phonemes and their distribution imposed by the phonetic, phonological and phonotactic systems of the recipient language. Foreign sounds are replaced with similar sounds of the recipient language to keep the loan phonologically close to the original and to make its phonological shape more nativesounding. This phenomenon is referred to as 'phoneme substitution' (Broselow, 1992: 200). Haspelmath (2009) gives the example of the loan резюме [rez'ume]Fr. 'résumé' in Russian. Since Russian does not have front rounded vowels, French [y] turns into [ю], and the preceding consonant becomes palatalised.

\subsection{Orthographic assimilation}

The differences in the English and Russian writing systems determine the character of the orthographic representations of loans. Spelling of loans depends on the channel of borrowing: oral or written (Volodarskaya, 2002: 106). Speakers of the recipient language may use transcription (афтешей [afte sheiv] 'after shave'), transliteration (фронт-офис [front-ofis] 'front office', or a combination of the two (менеджер [menedzher] 'manager').

In a limited number of cases (mostly abbreviations), Latin script is used for loans in Russian (VIP, CD, SMS, PIN, PUC, HR, PR, etc.), which sometimes function on a par with the transcribed/transliterated variants ${ }^{6}$ :

VIP - ВИП/вип, CD - сиди/СиДи, SMS - эсэмэс, PIN - ПИН/nин, PUC - ПУК, HR - эйчар, $P R-$ nuap $^{7}$.

\subsection{Grammatical assimilation}

Grammatical assimilation involves assigning grammatical categories to loans. Russian is a language with a highly developed system of flexions that are used to denote grammatical categories. Each new word needs to be referred to one of the grammatical classes irrespective of whether the same categories exist in the donor language and sometimes irrespective of the linguistic means the donor language uses. For example, the loan байк [baik] 'bike' is referred to $2^{\text {nd }}$ Declension Masculine nouns because it does not have a suffix at the end similar to Russian nouns that belong to this category.

\subsection{Semantic assimilation}

When a word is borrowed, it is usually the case that only one sense of a possible plethora of meanings is borrowed at a time (Busse and Görlach, 2002: 27). The loan's integration into a semantic field may involve a change of its meaning, both in denotation and connotation (Ibid.), which is commonly called semantic assimilation. In the process of semantic assimilation, the original meaning of the word may be either extended or specified (Kimyagarova, 1968). The case of the loan паркинг[parking] 
'parking' listed as "a place/building for paid secure parking" (Komlev, 2006) ${ }^{8}$ as opposed tопарковка [parkovka] 'parking', the noun motivated by an earlier loan парковать [parkovat'] 'to park' registered in the meaning 'bringing a car to a standstill" (Kotelova, 1984), is a good example of that.

\subsection{Derivational assimilation}

Derivational assimilation of a loan refers to its involvement in word-formation processes (Volodarskaya, 2002: 109), when it starts being used as a derivational base motivating new words and building different kinds of word families: word chains and word nests (Tikhonov, 2014: 621-622). Once loans start being involved in derivation, they participate in the sense creation process in a similar way as other words of the language. Concepts that are biologically, socially or culturally meaningful for a society are employed in the word-formation processes, i.e. are "derivationally marked" (Vendina, 1999: 16). Native speakers of the recipient language create derivatives using loans as bases according to their understanding of how the system of the language works. They then give new names to the objects that are important for them using this knowledge.

The choice of derivational material used for deriving new words from loans is believed to be important. Appearance of loan-based derivatives that carry connotational meaning not registered in a foreign word demonstrates the values of the conceptual content of a loan which native speakers of the recipient language accentuate by means of derivation. This can be noticed in hybrid formations, in which foreign roots are combined with indigenous Russian affixes (especially those primarily used in colloquial speech). As stated by Townsend (1968), the overall tendency in Russian wordformation is that foreign derivational means are usually employed for forming derivatives from foreign roots. For example, the blended derivative программист [programmist] 'computer programmer' motivated by the loanwordпрограмма [programma] 'programme' uses the foreign suffix -ucm [-ist] and is stylistically neutral. Deviation from this tendency and the use of a Russian suffix -щuк [-shchik], e.g. програмщик [programshchik] 'programmer' (colloquial), results in the change of the stylistic status of the concept the derivative denotes and produces a humorous effect, thus downgrading the value of the concept.

An interesting case for analysis is presented by the derivatives formed on the basis of the compound бизнесмен [biznesmen] 'business man'. Even though it seems derivationally analysable due to the recurrence of the first element in a number of бизнес $+N$ 'business $+\mathrm{N}$ ' compounds in Russian, it was borrowed as a single unit and is assimilated accordingly. Almost all derivatives based on this loan belong to expressive vocabulary and convey negative connotations:бизнесменишка[biznesmen-ishk-a] 'small, unsuccessful businessman', rude; бизнесменчик[biznesmen-chik] 'a businessman with a very small business', humorous; бизнесменша[biznesmen-sha] 'business woman', rude; бизнесменка[biznesmen-ka] 'business woman', humorous; бизнесменствовать [biznesmen-stvo-vat'] 'do business', humorous; 
бизнесменствующий [biznesmen-stvu-yushch-yi] 'doing business', humorous. The humorous effect in the first two examples (бизнесмениика and бизнесменчик) can be explained by the use of diminutive suffixes. In the case with бизнесменша and бизнесменка the presence of additional connotations can be attributed to the use of gender-marking suffixes, implying that business is not suitable for a woman. However, the last two cases бизнесменствовать and бизнесменствуюший employ stylistically neutral suffixes.

This allows for a speculation that the use of indigenous Russian suffixes may be responsible for the derivatives of most recent borrowings becoming stylistically marked even in cases when the suffix is productive and forms neutral derivatives in Russian. For example, the agentive suffixes $-\varkappa и \kappa$ [-shchik] and $-н и \kappa$ [-nik] are used to form nouns from verbs to name people or things related to activities named by the root, e.g. танцовщик [tantsovshchik] 'dancer', буксировщик [buksirovshchik] 'towing machine', шутник [shutnik] 'joker', работник [rabotnik] 'worker'. When used in combination with a recently borrowed root, the derivatives may sound odd, especially in cases when a more acceptable form with a foreign suffix already exists in the language, as is the case with программист [programmist] 'computer programmer'. Adding suffixes to mark loans for feminine gender produces a similar effect, e.g. блоггериа [bloggersha] 'female blogger', интернетчища [internetchitsa] 'female internet user'.

Even though the research that looks at hybridisation as the means of assimilation of loans seems to be on the rise in Russian linguistics, there does not seem to be much work devoted to the influence of the use of different derivational means on the assimilation of loans. A study that would address this issue would be beneficial for better understanding of peculiarities of assimilation mechanisms in Russian.

\section{English $\mathbf{N}+\mathbf{N}$ compounds in Russian}

We have seen that assimilation of a loan in a language undergoes stages, with derivational assimilation usually being the last. It is difficult to predict how long it may take for a word to be fully assimilated in a language, since several factors are involved, including the formal characteristics of the word, its communicative value, frequency of occurrence, the register in which the word is used, and the importance of the referent for the speakers. If we assume that $\mathrm{N}+\mathrm{N}$ compounds are words, the question we can ask is: what does it take for such words to become assimilated? Based on the discussion above, one of the most important markers of successful assimilation of a loan is derivational assimilation. We have seen, however, that Russian has extensive derivational means for individual words to be successfully assimilated in the language, so the reasons for borrowing $\mathrm{N}+\mathrm{N}$ compounds and using the compound formation pattern are somewhat unclear. The discussion below looks at the possible explanations for this phenomenon.

\subsection{Russian $\mathrm{N}+\mathrm{N}$ data}


As noted in the Introduction, this investigation is part of a larger corpus-based project in which a database of 2,000 Russian analytical composites was collected and analysed. What follows is a brief outline of the whole study, then the discussion is narrowed down to the analytical $\mathrm{N}+\mathrm{N}$ composites with a loan abbreviation in the modifying position.

The criteria for the Russian $\mathrm{N}+\mathrm{N}$ composites to be included in the analysis are as follows:

1. The first element of the analytical composite is a loanword, which was borrowed and/or came into productive use relatively recently (starting from the 1990s); e.g., интернет [internet] 'the Internet', фешн [feshnn] 'fashion'. Earlier loans like бизнес [biznes] 'business' and риск [risk] were included if they were borrowed as part of $\mathrm{N}+\mathrm{N}$ compounds to refer to novel concepts, e.g. бизнесрешение [biznes-resheniye] 'business solution', риск-менеджмент [riskmenedzhment] 'risk-management'.

2. The first element must be used analytically (i.e. without grammatical markers) in the composite irrespective of the syntactic position, gender of the noun and plurality of the head.

3. Neither element of the composite should be unique; i.e., elements recur in the language in the same structural form and the same (or similar) meaning either as free lexemes or as components of other composites.

4. The composite should be semantically and morphologically transparent. Examples like пинг-понг [ping-pong] 'ping-pong', купюр-цензура [kupyurtsenzura] 'censorship', тай-брейк [tai-breik] 'tiebreak' were borrowed into Russian as chunks to denote the concepts that were new for Russian culture. They appear to be morphologically divisible; however, this division is only possible because of the orthographic representation.

5. The analytical element cannot be a truncated adjective/noun. The reason for including this criterion into the list is determined by the fact that the truncated adjective + noun pattern is very productive in Russian. This criterion was the most difficult to observe since in some cases (e.g., cnopm $+N($ sport $+\mathrm{N})$ composites) defining the first composite as a noun (and not a truncated form from the adjective спортивный [sportivnyi] 'relating to sport') can only be based on the etymological data (Chernykh, 1999; Fasmer, 1986), which is not always complete and/or precise.

Observation of these criteria was important for the research since they allow for deeper understanding of the reasons for $\mathrm{N}+\mathrm{N}$ compounds (rather than individual words) to be borrowed into Russian.

Several constituent families that satisfy the search criteria and that have the largest number of composite types were chosen for the analysis. The leftmost elements of the collected composites were approached from the viewpoint of their morphology to determine the factors that encourage the formation of analytical constructions. It was noticed that most $\mathrm{N}+\mathrm{N}$ analytical composites contain loanwords both as the head and as 
the modifier. It was pointed out above that once loanwords start motivating the formation of new words in the target language, the derivational material (suffixes and prefixes) used for building paradigms with foreign roots are usually of foreign origin (Townsend, 1968). The same seems to hold true for the formation of composites containing a loan element, and the number of novel coinages with both words being loans should then be expected to be higher than the number of formations in which one element is a loanword and the other one is a Russian word.

The head element in the collected sample is usually represented by a grammatically and derivationally assimilated loan which often has lost its novelty in the language; e.g., интернет-технология [internet-tekhnologiya] 'internet technology', видеосалон [videosalon] 'video salon', онлайн-конференция [onlain-konferentsiya] 'online conference'.

The leftmost (analytical) element in more than $90 \%$ of the composites under discussion is represented by the latest loanwords, borrowed mainly from English. The analytical elements usually refer to notions that have become important in recent times. With the disappearance of the "iron curtain", Russian culture was flooded with objects, concepts and phenomena that were not accessible to people during Soviet rule. The massive number of loans from English at the end of the $20^{\text {th }}$ century can be explained by the radical changes in the life of the country. Since Russia was isolated from the Western world for most of the century, the information that was coming from behind the "curtain" was strictly censored and the Western lifestyle was severely criticised. Therefore, developments in many spheres of life, changes in attitudes to political, societal and economic matters, and achievements in culture and science were new to the Russian lifestyle once the political and social situations in the country changed.

According to the collected corpus, the spheres of entertainment and business have acquired the largest number of loans. The other areas include: sports (фитнессинструктор [fitness-instruktor] 'fitness instructor', допинг-контроль [dopingkontrol'] 'doping control'); fashion (имидж-студия [imidzh-studiya] 'image studio', фешн-шоу [feshn-shou] 'fashion show'); and IT (веб-сайm [veb-sait] 'website', интернет-конференция [internet-konferentsiya] 'online conference'). Since the examples for this research were collected from current Russian print media (newspapers and magazines) aimed at a general audience, the data cannot accurately reflect changes in more specific areas.

The collected examples fall into three distinct groups:

(1) The first element in the composites has the characteristics of a $2^{\text {nd }}$ Declension, masculine noun. This group is the biggest in terms of the number of examples and in terms of the variety in the loan components. The composites of this group are structurally similar to Russian compounds with a first element truncated, e.g. спорт-площадка [sport-ploshchadka] 'sports grounds' from спортивнаяплощадка [sportivnaya ploshchadka] 'sports grounds'.

(2) The first element in the composites ends in a vowel $-o$, $-e$ or $-a$, andis morphologically unassimilated (i.e., it often does not have an inflectional 
paradigm). The composites of this group are structurally similar to Russian compounds with a connecting vowel, e.g. хлебозавод[khlebozavod] 'breadmaking plant').

(3) The first element is represented by a loan abbreviation (henceforth - LA) that acts as a word, e.g. вип-зона [vip-zona] 'VIP zone'.

This investigation focuses mainly on the third group and attempts to analyse the assimilation patterns that LAs demonstrate. The main reason for choosing this group is that $\mathrm{LA}+\mathrm{N}$ composites are the most recent phenomenon and thus provide a clearer picture for analysis. The next part of this paper looks at how the system of the Russian language accommodates LAs through their use in analytical composites.

\subsection{Abbreviation}

"Abbreviation" (or shortening), in the most general sense, is a type of word-formation in which the elements are reduced to the initial letters and/or syllables of constituting lexemes (Crystal, 2008). Abbreviation serves as an example of the tendency to an economical use of language, thus raising the communicative value of language items. Abbreviation is an umbrella term for formations that include initialisms (USA, $F B I$ ), acronyms (NATO, UNO), and clippings (Fro from Afro, op art for optical art). ${ }^{9}$ Initialisms are opposed to acronyms, which are abbreviations pronounced according to the rules of the phonological system of the language, e.g. NATO ['neItəU] (for North Atlantic Treaty Organisation), ANZAC ['ænzæk] (for Australian and New Zealand Army Corps), OPEC ['əupkk] (for Oil Producing and Exporting Countries). Both acronyms and initialisms are products of word-formation, since they possess lexical meaning and can be employed for further derivational operations (in the same way as coinages and loans). At the initial stages of their formation, the meaning of abbreviations is motivated by the meaning of the words that constitute them; this motivation tends to be lost with time. The term "abbreviation" will be used to refer to two main types that are analysed in the current research-that is acronyms and initialisms - because these are the two main types found in the collected data set.

\subsubsection{Lexicalisation of abbreviations}

If we assume that abbreviations function in the language in a similar way to regular words, it is possible to speak about their lexicalisation. In the case of lexicalised abbreviations, there is no need for analysis of the compressed structure; we are taken straight to the concept that is labelled with an abbreviated form. The more frequently an abbreviation is used, the sooner its referent becomes known to the language users, and the sooner it loses its connection with the motivational base. The process of demotivation of abbreviations may be followed by their orthographic and derivational assimilation. In this case abbreviated lexemes may start being used as derivational bases and start forming paradigms. The word laser (Light Amplification by Stimulated 
Emission of Radiation), demonstrates how the term may lose its connection with the motivational base, because the latter is not important for native users of the language. It has the spelling of a regular word, and it is used in two meanings: 'a kind of beam' and 'a unit that emits this type of beam' (neither of which has the reference to the process, originally present in the motivational base). It also has forms laser and lasers and is perceived as a cognitively whole notion.

As English is an analytical language, the tendency for lexicalised abbreviations to be used as motivational bases is not very strong even in the case of acronyms. The derivational activity of these lexical units is revealed in the formation of compounds in English where they realise the derivational potential by forming extended paradigms; e.g., US Army, US Navy, US government, US Cabinet; FBI certificate, FBI agent, FBI recruitment policy, FBI unit.

\section{3. $\mathrm{LA}+\mathrm{N}$ composites}

The current investigation looks at the results obtained from the analysis of around 600 types of Russian analytical composites, in which the first element is represented by a loan abbreviation (LA). The purpose of the analysis is to look at the ways in which LAs are assimilated, with special attention to their use in analytical composites.

The first question to ask is whether LAs have the potential to be assimilated in the recipient language (Russian) and what it means for an LA to become assimilated.

When an abbreviation is borrowed, it is perceived by the speakers of the recipient language as an indivisible lexical unit, which requires an explanation since the concept it refers to may not be familiar to the speakers.

В Америке их около десятка - кроме упомянутых ЦРУ и ФБР, ещё АНБ (Агентство н циональной безопасности), РУМО (Разведывательное управление Пентагона), дейс твующие автономно разведки различных видов вооружённых сил, информационная слу жба государственного департамента и немало других ведомств.

There are about a dozen of those in America, apart from those mentioned; i.e., the CIA and the FBI, there is also the NSA (National Security Agency), the DIA (Defence Intelligence Agency), some autonomously acting intelligence agencies of different kinds of armed forces, the information service of the Department of State, as well as many other departments.

The examples above ${ }^{10}$ may be used to demonstrate how the well-known abbreviations referring to CIA and FBI are opposed to NSA (National Security Agency) and DIA (Defence Intelligence Agency), which require an explanation. If the abbreviation is used frequently and its referent is known to the majority of speakers (which is often determined by the longevity of the LA in the language and its frequency of occurrence in general contexts), the explanation is not required. This process is the same for loanwords, especially in the case of "loanwords by necessity", or "cultural borrowings (Haspelmath, 2009: 46).

Another argument supporting the suggestion that abbreviations (and LAs) are perceived as indivisible units is their use in the so-called tautological compounds; e.g., 
VIP-nерсона [VIP-persona] 'VIP-person', SMS-сообщение [SMS-soobshchenie] 'SMS-message', IT-технология [IT-tekhnologiya] 'IT-technology'. ${ }^{11}$ In such compounds, an abbreviation loses its connection to the motivational base (words comprising the abbreviation), which justifies the fact that abbreviations tend to become lexicalised and be perceived as single lexical units.

\subsection{Assimilation of loan abbreviations}

If LAs are perceived as words, it is possible to suggest that they function as words too. Therefore, the process of their assimilation should match the assimilation of regular loans. The same criteria should be in place for determining the potential for an abbreviation to be assimilated in the recipient language. An assimilated abbreviation should thus:

- Be orthographically represented by the means of the recipient language (ФБР for FBI).

- Be assigned a grammatical category ( $Б \supset P$ is tagged as an inanimate, singular noun of neuter gender). ${ }^{12}$

- Be semantically assimilated. Since the loan $Ф Б Р$ denotes a foreign organisation, we cannot see the semantic extension. However, no explanation of meaning for ФБР is given in the analysed texts, which suggests that it is semantically assimilated.

- Participate in the derivational processes.

The status of the loans that are abbreviations in the source language is not always clear in Russian. Based on their degree of assimilation, it is possible to identify the following groups.

\subsubsection{Transplants}

LAs that use the orthography of the donor language are often called transplants or barbarisms. The tendency for LAs to be used in their original spelling is quite strong and is preserved even when forming composites, e.g. PC-системa [PC-systema] 'PC system', VIP-зал [VIP-zal] 'VIP hall', CD-nлеер [CD-pleyer] 'CD player', $P R$ кампания [PR-kampaniya] 'PR campaign', etc.

\subsubsection{Graphically assimilated abbreviations}

LAs that acquired Russian orthographic representation are graphically assimilated. Some of them demonstrate the principles of transcription, preserving the pronunciation of the etymon, e.g. сидu (from CD), nuсu (from PC), nuap (from PR). Others demonstrate the principles of transliteration, e.g. Bun [vip] (from VIP). It is also often 
the case that one and the same concept can be represented in the language by a graphically assimilated abbreviation and a transplant. For example, the LA bun can occur both in Russian and English orthography. ${ }^{13}$

\subsubsection{Lexically assimilated abbreviations}

The next stage of assimilation of LAs refers to the condition in which the constituents comprising a loan are translated; e.g., ЦРУ (for CIA), ФБР (for FBI), ПК (for PC). In Haugen's (1950) classification such loans are viewed as kinds of semantic borrowing, which includes loan translation (calques), loan rendition and loan creation (Fischer, 2008: 6). In the case with lexically assimilated abbreviations, it is possible to suggest that we deal with calques; however, the syntactic nature of the source phrases is not homogeneous. ${ }^{14}$ In order to avoid confusion, a more generic term is used here.

\subsubsection{Grammatically assimilated abbreviations}

When we talk about abbreviations, the distinction between grammatical assimilation and derivational assimilation is hard to draw in Russian. Once an LA starts developing an inflectional paradigm, it is possible to suggest that it becomes grammatically assimilated; e.g., випьl [vipy] 'VIP.P1Gen', СПИДа [SPIDa] 'AIDS.Gen'. Assimilation on the grammatical level does not always require assimilation on the lexical level (translation of the constituents). For example, such LAs as ВИП/вun [VIP] 'VIP' andnuap [piar] 'PR' are not lexically assimilated, but they may still be marked for case and gender when required by syntax of the construction. ${ }^{15}$

У нас просто меньше лицемерия и пиара. (piar.a [piar.Gen])

(We just have less of hypocrisy and PR.)

Мероприятие представляет собой танцевальную промо-акцию для журналистов, VIPoв(VIP.ov [VIP.PIGen]), представителей прессы, промоутеров, диджеев...

(The event represents in itself a dance promotion campaign for journalists, VIPs, media representatives, promoters, DJs...)

Overall, the number of grammatically assimilated LAs is quite low in the collected data set. Examples include BASIC, PIN, VIP, and some others.

\subsubsection{Derivationally assimilated abbreviations}

Once an abbreviation starts being used as a derivational base, we can talk about its derivational assimilation. Derivatives that are formed on the basis of LAs may include units at any stage of assimilation starting from transplants: VIРовский [VIPovskiy] 'typical of/aimed at VIPs' and orthographically assimilated units: пиарщик [piarshchik] 'PR-specialist' to lexically assimilated units: ФБРовиы [FBRovtsy] 'FBI officers'. The number of abbreviations that are used as derivational bases is limited, which is probably 
determined by the generally low derivational potential of abbreviations. LAs are widely used in $\mathrm{LA}+\mathrm{N}$ sequences instead. The reasons for this and some implications are discussed below.

\subsection{Peculiarities of assimilation of loan abbreviations}

As shown above, assimilation of a loanword follows distinct stages. The overall tendency is that one stage includes the previous; i.e., from phonological assimilation to derivational assimilation. This means that a derivationally assimilated loan needs to be assimilated on other levels as well. This does not seem to be the case for abbreviations. The analysis of abbreviation-based derivatives shows that the process is somewhat sporadic. For example, it is noticed that a transplanted form and its russified word-like version function in the language simultaneously as the examples from the RNC (n.d.) demonstrate.

\section{PRvs. пиар (piar)}

Только на наружную рекламу, социологические исследования и PR было потрачено не м енее 8 млн.

(No less than 8 million was spent just on outdoor advertising, case studies and PR.)

Что сегодня первично: война или пиар - понять довольно сложно.

(It is hard to understand what comes first nowadays: war or PR)

\section{вип/ВИП vs. VIP}

И если не решить этот вопрос кардинально, очередная вип-авария может иметь самые неприятные политические последствия.

(And if we do not resolve this issue, another VIP-accident may have most unpleasant political consequences.)

Кроме высоких гостей президента Путина, в город зачастили и другие VIP- персоны. (In addition to President Putin's high guests, other VIPs started to visit the city quite often.)

\section{SMS/smsvs. CMC}

А в Москве в ближайшее время впервые в стране начнет работать служба smsоповещения о состоянии воздуха в разных районах города.

(In the near future in Moscow an sms-alert service informing about air quality in different areas of the city will start functioning for the first time in the country.)

И, к сожалению, вычеркнуть подобное из памяти невозможно, это не СМС на телефоне, которое можно стереть и забыть, это остается с тобой.

(And, unfortunately, it is impossible to cross it out from the memory, it is not an SMS on your phone, which can be erased and forgotten; it stays with you forever). ${ }^{16}$

There may be several reasons for this. Firstly, such LAs may be considered cultural borrowings which denote phenomena borrowed at the same time (Haugen, 1950). The Russian translation of the phrase that stands for an LA does not always render the exact meaning, especially in the early stages of a loan's functioning, or the meaning of the Russian phrase may be misleading. ${ }^{17}$ For example, if we translate the abbreviation $P R$ (public relations) into Russian, without knowing what the term stands for, the phrase публичные отношения (public relations) may well be understood as 'somebody's 
relations in front of the public', which is not exactly what the term $P R$ implies. ${ }^{18}$ Moreover, this can serve as an example of the clash of cultural values, because demonstrating peculiarities of your life in public is considered inappropriate. The use of the neutral term nuap (PR), on the other hand, allows for avoiding such traps.

Another explanation is offered by Rochtchina (2012: 79-80), who believes such cases to be examples of 'double orthography', which uses the principles like those in the Japanese script whereby two alphabets (katakana - for more recent loans, and hiragana - for native Japanese and loans from Chinese) act simultaneously.

Another reason may be pragmatic. LAs are a compact way of representing complex concepts. Word-like versions of English abbreviations are perceived as conceptually whole units, and since the loans of this kind are morphologically non-transparent, the meaning of the whole is not motivated by the semantics of the components. Therefore, translating the phrases to produce Russian abbreviations will break the cognitive unity of the concept. It will also require more complex morphological-semantic processing and speakers will need knowledge of what the given letters stand for. Considering the tendency for economy in language, the use of a well-established item that is listed in the vocabulary receives priority.

\subsection{Limitations on assimilation of loan abbreviations}

Derivational potential of LAs can be considered an important factor for their assimilation in Russian. The concept of "derivational potential" is offered by Dyakov (2001), who uses a set of criteria allowing to predict whether a word can or cannot be successfully assimilated in the recipient language. The outline below demonstrates how different factors affect assimilation of LAs in Russian.

\subsubsection{The role of phonology}

As with loanwords, the most important factor that has an impact on the assimilation of LAs in Russian is conformity with the phonetic/phonological system of the language. ${ }^{19}$ For example, the final vowel $-u$ in LAs like $c u \partial u$ [sidi] 'CD' is not typical of Russian singular nouns, which points to the low derivational potential of words with this ending. As a result, abbreviations ending in $-u$ are more likely to be used as transplants in their original English spelling as parts of $\mathrm{LA}+\mathrm{N}$ composites; e.g., $C D-$ диск[CD-disk] 'CD-disk', PC-приложение [PC-prilozheniye] 'PC application'.

LAs of such kind may still be used as lexemes and derivational bases; however, this use is limited to colloquial speech or professional jargon, e.g. сидюк [sidyuk] 'CDplayer/CD-ROM', дивидюк [dividyuk] 'DVD-player', дивидиика [dividishka] 'DVDdisk'. Such russified versions are stylistically coloured and belong mainly to expressive vocabulary (Rochtchina, 2012: 78). This effect is enhanced by the use of Russian suffixes that are typical of colloquial speech. For example, references to the derivatives formed on the basis of the LA сиди [sidi] 'CD', such as сидюк[sidyuk] 'CD-player', сидюшник[sidyushnik] 'CD-player' or 'CD system', сидюшный [sidyushnyi] 'relating to CD', in a Google search demonstrate that the words usually occur in IT blogs and 
forums. The definitions of such words may or may not be given in dictionaries of computer and young people's jargon:

Мы отцепили сидюк, стали цеплять хард, два часа мучились, а комп харда не видит.

(We unhooked the CD-player and began to hook the hard drive; after two painful hours the computer still didn't «see» the hard drive.)

Давай диски в сидюшнике поменяем, надо нового чего-нибудь послушать!

(Let's change the discs in the CD system, we need to listen to something new!)

Валялся какой-то кассетно-сидюшный в гараже с небольшими колонками типа филипс. Если интересует, посмотрю в каком состоянии.

(There was one cassette-CD player in the garage with small speakers, probably Phillips. If you are interested, I'll check its condition.)

These examples of LAs have a limited derivational potential in terms of their phonology. Interestingly, the same holds true for cases that are not limited by the phonological system of Russian. LA-based derivatives like ФБРовиьь 'FBI officers', ЦРУиники 'CIA officers' also demonstrate the presence of negative connotations, which can be tracked through the use of such derivatives in negative contexts in the Russian media. Derivatives like these are mainly used in interviews and blogs rather than bulletins and analytical reports; their use in broadsheets seems to be restricted.

Only very few LAs may be considered successfully assimilated, where the derivatives formed on the basis of the assimilated abbreviation are perceived as the norm of the language and are frequently used in neutral contexts. The loan nuap [piar] 'PR' may serve as a good example of this. Vaganova (2005) lists seven derivatives that use the loan as a derivational base; e.g., nuарить[piarit'] (ImpV), пропиарить [propiarit'] (PerfV), отпиарить [otpiarit'] (PerfV), пиарщик [piarshchik] (AgtN), пиармен [piarmen] (AgtN), пиарология [piarologiya] 'PR-ology' (N), пиаролог[piarolog] 'PR scientist' $(\mathrm{N})$. The choice of the derivational material is important too. The derivatives with Russian suffixes, i.e. nuapumb[piarit'] 'to PR', nропиарить [propiarit'] 'to have PRed', omnuapumb [ot-piar-it'] 'to have PRed', пиаршик [piarshchik] 'PR specialist', all have somewhat negative connotations. At the same time, derivatives that employ foreign suffixes are stylistically neutral, e.g. пиармен [piarmen] 'PR specialist', пиарология [piarologiya] 'PRology', пиаролог [piarolog] 'PR scientist'.

So, we can see that the trend for the changes in meaning in the process of derivational assimilation of loans (See in Section 3.5 above) can be noticed in the assimilation of LAs too. The fact that this trend is not limited to loanwords is interesting and confirms the suggestion that the use of indigenous Russian derivational material may be responsible for pejoration of the meaning of the concept expressed by the foreign stem, which creates a humorous effect.

\subsubsection{The role of prestige/novelty}


Another factor that limits the assimilation of the loan is the loss of novelty and/or prestige, and the use of Russian derivational means can be considered a contributor. As pointed out above, derivatives formed on the basis of assimilated abbreviations have a limited range and are more typical of colloquial speech. Thus, it is possible to speculate that with limiting the register in which a loan is used, we may also expect changes in the meaning of the concept that the loan-based derivative denotes. On the other hand, preserving the form of the loan (or the form of the LA), which is possible through the employment of the derivational means of foreign origin (foreign affixes) or the use of the foreign morphological pattern like $\mathrm{N}+\mathrm{N}$ compounding, allows for keeping its semantic structure and value in the eyes of the speakers intact. The analysis of LA+N sequences that refer to a person working in the IT sphere seems to demonstrate a higher level of respect to the profession compared to the assimilated LA айтишни (aitishnik 'a person that has something to do with IT'), cf. IT-эксnерm (IT-expert), ITпрофессионал (IT-professional), IT-менеджер (IT-menedger), IT-любитель (ITenthusiast). The russified version айтишник sounds colloquial, and for a native speaker conveys the meaning of someone who has some knowledge about/experience with IT, or even an amateur who can help sort out mundane computer-related problems.

So far, we have seen that through derivational assimilation, a loan or an LA (and the concept it denotes) may acquire additional connotations that are not present in the etymon and even lose its prestige and novelty in the eyes of the speakers of the recipient language. Besides the change in the stylistic status of the LA in the process of becoming derivationally assimilated, its general meaning may also change. For example, the loan ВИП [vip] 'VIP', which may orthographically be represented as a transplant VIP or as a word - bun, demonstrates this trend. If we compare the meanings conveyed by the modifying constituents in виповские места [vipovskie mesta] (vip.AdjPl seat.Pl) versus вun-места [vip-mesta] 'VIP-seats', the meaning conveyed by the derivative in виповские can be understood as "cool", "prestigious", which is part of the connotations of the meaning of the original concept expressed by the LA вun/ВИП/VIP, but not its core semantic content. At the same time, the meaning of the analytical composite Bunместа 'VIP seats' is correlated with the semantics of the English etymon, i.e. 'seats for VIPs'.

\subsection{Alternative route for assimilation}

As can be seen from the discussion above, LAs have the potential to become assimilated in the recipient language, with derivational assimilation being the final stage of a loan becoming russified. After such russification, loans tend to undergo changes in their meaning and are more likely to be used in colloquial speech. This means that in the process of assimilation concepts denoted by loans in general (and LAs in particular) may lose some of the characteristics they were initially borrowed for. The need to preserve the conceptual value of loans seems to be connected with preserving their form. Therefore, the use of LAs in analytical composites, where there is no need for grammatical and derivational assimilation, can be viewed as an alternative route that allows for compensating the aforementioned limitations associated with derivational 
assimilation. The number of $\mathrm{N}+\mathrm{N}$ composite rows with LAs in the modifying position supports this argument.

\section{CD}

$C D$-обзор[CD-obzor] 'review of new CDs', CD-раздел [CD-razdel] 'CD profile', $C D$ чейнджер [CD-cheindzher] 'CD changer', CD-проигрыватель [CD-proigryvatel'] 'CD player', $C D$-диск [CD-disk] 'CD disc', CD-сборник [CD-sbornik] 'collection of songs on a CD', CD-архив [CD-arkhiv] 'CD archive', CD-плейер [CD-pleyer] 'CD player', CD-nарад [CD-parad] 'ranking of CDs', CD-ресивер [CD-resiver] 'CD receiver', CD-бокс [CD-boks] 'CD box', CD-носитель [CD-nositel] 'CD-ROM', CD-текст [CD-tekst] 'CD text', CDдиагноз [CD-diagnoz] 'diagnostics of the CD drive', CD-продукция [CD-produktsiya] 'CDs that are sold'

\section{ВИП/VIP}

ВИП/VIP-мнение [VIP-mnenie] 'opinion of a VIP',ВИП/VIP-персона [VIP-persona] 'VIP person', ВИП/VIР-категория [VIP-kategoriya] 'category of products of very high quality'), ВИП/VIР-клиент [VIP-klient] 'VIP client', ВИП/VIР-версия [VIP-versiya] 'a version of a product that is suitable for VIPs',ВИП/VIP-варианm [VIP-variant] 'a version of a product that is suitable for VIPs', ВИП/VIP-отель [VIP-otel'] 'hotel where VIPs stay', ВИП/VIPперевозчик [VIP-perevozchik] 'carrier of VIP cargo',ВИП/VIP-автомобиль [VIP-avtomobil'] 'VIP car', ВИП/VIP-захоронение [VIP-zahoronenie] 'burial place for VIPs',BИП/VIPучасток [VIP-uchastok] 'a piece of land for VIPs', ВИП/VIP-подписка [VIP-podpiska] 'VIP subscription',ВИП/VIP-лииа [VIP-litsa] 'VIPs', ВИП/VIP-проход [VIP-prohod] 'an aisle or door reserved for the use of VIPs']

\section{IT}

IT-отдел [IT-otdel] 'IT department', IT-департамент [IT-departament] 'IT department', ITэксперт [IT-expert] 'IT expert', IT-технология [IT-tekhnologiya] 'IT technology', IT-город [IT-gorod] 'city for IT specialists and their families', IT-бизнес [IT-biznes] 'IT business', ITкомпания [IT-kompaniya] 'IT company', IT-ипотека [IT-ipoteka] 'mortgage with special conditions for IT specialists', IT-сфера [IT-sphera] 'IT sphere', IT-решение [IT-resheniye] 'IT solution', IT-разработка [IT-razrabotka] 'product developed by IT specialists', IT-проекm [IT-proekt] 'IT project'

\section{PR}

$P R$-поддержка [PR-podderzhka] 'PR support', $P R$-команда [PR-komanda] 'PR team', $P R$ акиия [PR-aktsiya] 'PR campaign', $P R$-тендениия [PR-tendentsiya] 'PR tendency', $P R$ вопрос [PR-vopros] 'PR issue', PR-отдел [PR-otdel] 'PR department', PR-менеджер [PRmenedzher] 'PR manager', PR-департамент [PR-departament] 'PR department', $P R$ директор [PR-direktor] 'PR director', PR-специалист [PR-spetsialist] 'PR specialist'

\section{SMS}

SMS-оповещения [SMS-opoveshcheniya] 'SMS notification', SMS-технология [SMStekhnologiya] 'SMS technology', SMS-рассылка [SMS-rassylka] 'SMS mass texting', SMSспам [SMS-spam] 'SMS spam', SMS-информирование [SMS-informirovanie] 'informing via text messaging', SMS-уведомление [SMS-uvedomlenie] 'SMS notification', SMS-выписка [SMS-vypiska] 'bank statement that can be received via SMS', SMS-nароль [SMS-parol'] 'online access code that is sent via SMS', SMS-onpoc [SMS-opros] 'SMS survey', SMS- 
голосование [SMS-golosovanie] 'voting via SMS', SMS-сервис [SMS-servis] 'SMS service', SMS-траффик [SMS-traffik] 'SMS traffic', SMS-стандарт [SMS-standart] 'SMS format'

As can be seen from the examples, some of the $\mathrm{N}+\mathrm{N}$ composites with LAs could have been borrowed as single units (e.g., IT-технология [IT-tekhnologiya] 'IT technology') or as loan translations (Haugen, 1950), (е.g., CD-проигрыватель [CDproigryvatel'] 'CD player'). Some have been formed in the recipient language (e.g., ВИП/VIР-захоронение [VIP-zahoronenie] 'burial place for VIPs').

The discussion in this section aimed to demonstrate that the use of LAs in the modifying position of $\mathrm{N}+\mathrm{N}$ composites is one way to avoid the limitations outlined above. Since the first component of such sequences is used analytically, the derivational potential of the LAs is not important, as we can see in the case with $C D+N$ composites that form an extensive composite row. Preserving the form of the LA also preserves its original meaning and prestige. In addition, the combination of the LA with another noun avoids the necessity for it to be assimilated on grammatical and derivational levels, which helps to deal with restrictions set by the syntactic system of Russian. The use of LAs in Russian analytical composites can be also considered a special model of hybridisation, in which a whole word is used as a means of accommodating a loan into the recipient language.

\subsection{The use of LAs in Russian composites: old vs. new}

The last question to touch upon in the frame of this investigation is whether it is right to say that through borrowing of English $\mathrm{N}+\mathrm{N}$ compounds or $\mathrm{LA}+\mathrm{N}$ compounds Russian has also borrowed/developed a new word-formation pattern. The use of such structures in the creation of new $\mathrm{LA}+\mathrm{N}$ composites can be viewed as evidence that the language has accommodated not only the loans themselves but also the word-formation pattern. Rochtchina (2012: 80) claims that the number of LA+N compounds created from Russian material (РИА-Новости [RIA-novosti] 'RIA News', БТК банк [BTK-bank] 'BTK bank', ТВ-программа [TV-programma] 'TV programme', etc.) demonstrates that "... Russian morphosyntax is adopting an English structure." Even though this research does not entirely support this claim, there is certainly sufficient evidence that Russian is moving towards analytism under the influence of linguistic borrowing. Similar trends have been noticed in other Slavic languages, including Czech (Gazda, 2008), Bulgarian (Bagasheva, 2016), Polish (Sztencel, 2009), as well as Romance languages, e.g. French (Picone, 1996)

Intriguingly, indigenous Russian abbreviations and abbreviations that were borrowed during the Soviet times function somewhat differently from recent LAs. For example, the data in the RNC (n.d.) suggests that Russian-originating abbreviations are rarely used in the formation of composites, but are rather used as post-modifiers in noun phases, e.g. oфиuер $Ф \Phi[$ ofitser $\mathrm{ChF}]$ - ofitser $_{\text {Nom. }}$ Chernomorskogo ${ }_{\mathrm{Gen} .}$ Flota $_{\mathrm{Gen} .}$ 'Officer of the Black Sea Navy'; onepamopACУ[operator ASU] - operator $_{\text {Nom. }}$ Avtomatizirovannyh $_{\text {Gen. }}$ System $_{\text {Gen. }} U_{\text {pravleniya }}$ Gen. 'operator of ASU'). 
A possible explanation for this may be that the connection with the motivational base is preserved on a deeper level of mental representation, and the knowledge about how the full phrase is conventionally used (i.e. adnominal genitive construction: $\mathrm{N}+\mathrm{N}_{\text {Gen }}$, where LAs take the position of $\mathrm{N}_{\mathrm{Gen}}$ ) constrains the movement of the analytical element to the pre-modifying position.

The same is true for LAs that have been grammatically and lexically assimilated, are listed and are relatively high-frequency words. For example, LAs like HATO 'NATO', $O O H$ 'UNO', $C W A$ 'USA' are not involved in derivational processes and are used in syntactic constructions in a similar way to indigenous Russian loans; e.g., посол США 'USA ambassador', заседание OOH 'UNO meeting', сотрудник НАТО 'NATO official'.

Such positional constraints do not seem to be the case for most recently-borrowed abbreviations. One explanation that can be offered here is analogy. The meaning of a foreign abbreviation is often not motivated by the words the abbreviation stands for in the recipient language, and they are perceived by native speakers as foreign words/parts of words. Since one of the most prominent ways of introducing foreign words into Russian in the last few decades is through nominal compounding, LAs have become used in the pattern in which foreign words often occur-i.e. N+N. A similar phenomenon is registered in other languages. For example, Picone (1996) discusses the possibility of the influence of borrowed English $\mathrm{N}+\mathrm{N}$ compounds on the overall acceptance of right-headed elliptical $\mathrm{N}+\mathrm{N}$ sequences in modern French.

It is interesting, however, why older abbreviations are introduced into a syntactic structure by means of a genitival phrase. The study of available sources does not provide a definitive answer, which leaves the way open for speculation. One of the possible explanations may be that abbreviations borrowed earlier, especially during the Soviet rule, were introduced through official media channels. The structure of sequences was carefully checked by the censorship, one of the functions of which was editing the text in accordance with the prescribed rules of Russian. This may have influenced the way such structures are used. After the Soviet state fell apart, and especially with the advent of the Internet, the channels through which the information came into the country changed. The words that started to be borrowed denote the concepts that are relevant for people's everyday lives, which means that they have more communicative value for an individual. This may be considered one of the factors that can explain such change in the use of recent LAs.

It is also possible to speculate that in future, recently introduced LAs may start being used in a way that is more typical of Russian abbreviations: when abbreviation is used in adnominal genitive construction, e.g. сотрудникOOH (UNO officer). It is also possible that their use in compounds may remain preserved in the way it works now; i.e., $\mathrm{LA}+\mathrm{N}$. If the pattern passes the test of time, we will have more evidence for claims that the analytical compound formation pattern has been brought into use under the influence of borrowing a large number of English $\mathrm{N}+\mathrm{N}$ compounds.

\section{Conclusion}


This paper analysed a sample of analytical $\mathrm{N}+\mathrm{N}$ composites in Russian, paying special attention to the use of LAs in the leftmost (modifying) position. Based on the analysis, it is possible to suggest that the analytical $\mathrm{N}+\mathrm{N}$ pattern has become more productive in Russian under the influence of numerous borrowed $\mathrm{N}+\mathrm{N}$ compounds. However, the straightforward claim that through the borrowing of English $\mathrm{N}+\mathrm{N}$ compounds Russian also borrowed the analytical $\mathrm{N}+\mathrm{N}$ word-formation pattern seems premature. The position that takes into consideration the reasons behind the growing productivity of the pattern provides a firmer base for a grounded explanation of the issue. It is important to consider that a superficially similar analytical word-formation pattern already exists in Russian (e.g. царь-nушка [tsar'-pushka]'king cannon'). Since this pattern is unproductive, it is often disregarded in modern research on Russian analytical compounds. It is possible, though, that English $\mathrm{N}+\mathrm{N}$ compounds have triggered the revival of the pattern, which had previously existed. This revival brings with itself certain limitations; that is, the use of a recent loanword in the modifying position in the majority of cases and the predominant use of the word of a foreign origin in the head position.

The lack of clarity in terms of the reasons for growing productivity for Russian analytical $\mathrm{N}+\mathrm{N}$ composites makes it difficult to assess the scale of English influence on the Russian language. Accepting the position that the English $\mathrm{N}+\mathrm{N}$ pattern was borrowed under the influence of the large number of compounds, the contact between the two languages should be viewed as "more intense" (when some basic and non-basic vocabulary, as well as some structures are borrowed), according to Thomason and Kaufman's (1988) scale of borrowing. On the other hand, the position that views the use of the $\mathrm{N}+\mathrm{N}$ pattern as an example of revitalisation of an unproductive one, suggests that the contact between English and Russian is "casual" (with only lexical borrowings). Even though the presented study did not aim to investigate the scale of language contact, further research in this area will be helpful in understanding the reported analytical tendencies in Russian, which are attributed to the influence of English.

The discussion above touched upon the stages of assimilation of a loan in the new linguistic environment with special attention to the effects of derivational assimilation, which involves the use of different derivational means. In the process of derivational assimilation, loans in general and LAs in particular may acquire semantic characteristics which are not registered in their English etymons. Such changes may be attributed to the use of Russian derivational material (hybridisation), which brings in the meaning strongly associated with Russian words and creates a humorous effect.

Russification of the loan is also responsible for downgrading the value of the concept in the eyes of the native speaker of Russian, and sometimes pejoration of meaning even in cases with the use of stylistically neutral affixes. Further research on the influence of different derivational means in the process of the assimilation of the loan will allow for a better understanding of native speaker attitudes to the borrowed concepts as well as on the process of linguistic borrowing into Russian.

The need to preserve the conceptual value of the loans and/or LAs in the eyes of the native speakers of the recipient language seems to be strongly associated with the 
preservation of their structural form. The presented analysis suggests that the use of loan abbreviations in analytical composites, where there is no need for a loan to be assimilated (even on the orthographic level), can be viewed as a logical way to keep the formal characteristics of the loan, its semantic content and conceptual value intact. The use of LAs in the modifying position of $\mathrm{N}+\mathrm{N}$ composites also avoids the morphosyntactic restrictions of the Russian language system and compensates for the low derivational potential of some LAs. At this stage, we can see that the analytical $\mathrm{N}+\mathrm{N}$ pattern serves as a catalyst that brings new concepts into the system of the Russian language and is becoming more productive.

The use of Krysin's (1975) framework is determined by the necessity for looking at assimilation of loans as a gradual process, and views loans from the viewpoint of their degree of assimilation. A study that would explore the possibilities of categorising borrowings into Russian using more widely accepted classifications, e.g. Thomason and Kaufman's (1988) borrowing scale, Haugen's (1950) classification, Matras and Sakel's (2007) framework of MAT (matter) and PAT (pattern) integration of loans, Carstensen and Busse's (1994) classification of forms of linguistic transfer, etc. in order to contribute to the development of a typology of linguistic borrowing, would be valuable.

Another limitation of the current study is that it is clustered around a limited number of semantic domains of language use with the main focus on the use of the analytical $\mathrm{N}+\mathrm{N}$ pattern in technical language and business communication. Expanding the analysis beyond these areas and looking at the attitudes of native Russian speakers of different age groups towards this pattern will allow for employing a usage-based approach and will provide further insights into native speaker cognition.

\section{Notes}

1. Some of Haugen's (1950) categories are used where appropriate in this discussion.

2. This approach to treatment of the constituents of a Russian complex word raises questions connected with the terminology. For example, it is not clear whether understanding of the first constituent as a morpheme is determined by its representation by the stem or whether something else is going on. However, for reasons of space, and because the matters of terminology are not crucial for this investigation, I will refrain from discussing these here.

3. This assumption is rather simplistic for the purposes of the discussion. The criteria commonly used for differentiating between a compound word and a phrase in Russian also include structural (combination of two or more lexical centres, i.e. roots or stems, in a prescribed order), grammatical (the loss of grammatical markers by the first element), and semantic (unified meaning).

4. It has been pointed out by one of the reviewers that zhar-ptitsa may be a calque. This possibility cannot be excluded, since there are formations describing somewhat similar concepts in other Slavic languages, e.g. Czech pták ohnivák 'bird-fire' andSlovenian zlata ptic 'golden bird'. The analysed etymological sources do not provide a definitive answer to the question of the origin of this $\mathrm{N}+\mathrm{N}$ sequence, referring it to ancient Russian mythology. This example also supports the argument that classifications of loans that involve etymological 
principles may be somewhat misleading since it can be hard to draw a borderline between an indigenous word and a loan in the absence of phonological and/or morphological similarity.

5. Examples are taken from the RNC (n.d.).

6. Interestingly, in the RNC transplants (items using the script of the donor language) are tagged as barbarisms, whereas once the Cyrillic script is used, they acquire the status of a loanword.

7. Rochtchina (2012: 79) notes the overall tendency to preserve the English orthography in abbreviations that are related to information technology, e.g. DOS, IBM. She also points out that Cyrillic forms of abbreviations-e.g. Бu-бu-cu (BBC), МП3 (MP3)—often revert to their Latin alphabetic forms.

8. $C p$. Eng.:parking is motivated by the derivational base park and has the meaning 'bring (a vehicle that one is driving) to a halt and leave it temporarily, typically in a car park or by the side of the road' ("Parking", n.d., n.p.).

9. Matiello (2013) provides a detailed analysis of the issues that are associated with abbreviations in modern linguistics, including problems of definition, classification, irregularities in formation, etc.

10. Examples are taken from the RNC (n.d.).

11. This phenomenon is also referred to as RAS syndrome or PNS syndrome and is not limited to loan abbreviations. The phenomenon is widespread and supports the suggestion that abbreviations are perceived as words in general, e.g. English ATM machine [[Automated Teller Machine] machine], PDF format [[Portable Document Format] format].

12. The RNC (n.d.).

13. It is hard to say whether there is a tendency for the transplants to become graphically assimilated. The texts in the RNC contain at least ten times the number of examples of use of the LA VIP in the English orthography as compared to its number of uses in the Russian spelling вип/ВИП. The dates of the texts do not seem to matter either. Considering the limited size of the RNC, this cannot be considered representative of the overall tendencies, because a search in Google demonstrates that the use of the LA in the Russian orthography is quite common (over 200,000 hits).

14. For example, in the cases of ЦРУ (Eng.: CIA) and ФБР (Eng.: FBI), the syntactic structure of the source phrases in English and Russian do not match, which is not the case for $\Pi K$ (Eng.: PC). For a more detailed description of abbreviation calques and differences in their structure in Russian see Baranova (2010).

15. Examples are taken from RNC (n.d.).

16. Examples are taken from RNC (n.d.).

17. It is important to point out that the tendency for russification of English abbreviations is becoming stronger. However, some abbreviations can be considered successful translations, e.g. США (USA), ФБР (FBI).

18. This could have been the case for English too, before the expression public relations started to be used as a term.

19. Other criteria include the length of the loan, presence of semantic competition, conformity with the grammatical system of the language and importance of the concept to the speakers. Dyakov's (2001) understanding of derivational potential seems to be strongly correlated with Alain Rey's comments on neology in French (see Rey, 1995: 80-82).

\section{References}


Bagasheva, Alexandra (2016): "On $\left[\mathrm{N}_{1} \mathrm{~N}_{2}\right]$ constructions and word-formation in Bulgarian". In L. Körtvélyessy et al., eds., Word-formation Across Languages. Newcastle upon Tyne: Cambridge Scholars Publishing, 1-28.

Baranova, Lyudmila (2010): "Kalkirovanie kak sposob zaimstvovaniya inoyazychnyh abbreviatur v russkom yazyke". Сучасні дослідження 3 іноземної філології, http://nbuv.gov.ua/UJRN/Sdzif 201086 [Accessed 25 October 2017]

Bauer, Laurie (2003): Introducing linguistic morphology. Washington, DC: Georgetown U Press.

Broselow, E. (1992): "Loan phonology". In W. Bright, ed., International Encyclopedia of Linguistics: EXPL - MOOT. Oxford: Oxford University Press, 200-201.

Busse, Ulrich, and Manfred Görlach (2002): “German”. In M. Görlach, ed., English in Europe. Oxford: Oxford University Press, 13-36.

Carstensen, Broder, and Ulrich Busse (1994): Anglizismen-Wörterbuch. Der Einfl uss des Englischen auf den deutschen Wortschatz nach 1945. Berlin, New York: Mouton de Gruyter.

Chernykh, P.Y. (1999): Istoriko-etimologicheskyi slovar' covremennogo russkogo yazyka. $3^{\text {rd }}$ ed., Moscow: Russkyi yazyk.

Corbett, Greville (2004): "The Russian adjective: a pervasive yet elusive category". In R.M.W Dixon and A. Y. Aikhenvald, eds., Adjective Classess: A Cross-Linguistic Typology. Oxford: Oxford University Press, 199-222.

Crystal, David (2008): A Dictionary of Linguistics and Phonetics. $6^{\text {th }}$ ed., Oxford: Blackwell Publishing.

Dimitrova, Ludmila, et al. (2011): "Bulgarian-Polish-Lithuanian Corpus - Recent progress and application”. In D. Majchráková and R. Garabí, eds., Natural Language Processing, Multilinguality. Sixth International Conference Modra, Slovakia, 20-21 October 2011 Proceedings. Slovak National Corpus L. Štúr Institute of Linguistics Slovak Academy of Sciences Bratislava, Slovakia, 44-50.

Dyakov, Anatoly (2001): Derivatsionnaya integratsiya anglitsizmov v russkom yazyke kontsa $X X$ veka $v$ funktsional'nom aspekte. $\mathrm{PhD}$ dissertation, Novosibirskyi Gosudarstvennyi Pedagogicheskyi Universitet.

Fasmer, Max (1986): Etimilogicheskyi slovar' russkogo yazyka. $2^{\text {nd }}$ ed., Moscow: Progress.

Fischer, Roswitha (2008): "Introduction: Studying anglicisms". In R. Fischer and H. Pułaczewska, eds., Anglicisms in Europe: Linguistic Diversity in a Global Context. Newcastle upon Tyne: Cambridge Scholars Publishing, 1-14.

Gazda, Jiří (2008): "Rost analitizma (i agglutinativnosti) kak odna iz konvergentnych tendencij $\mathrm{v}$ razvitii sovremennych slavjanskich jazykov (na materiale novych slozhnych naimenovanij $\mathrm{v}$ russkom i cheshskom jazykach)". Izuchenije slavjanskich jazykov, literatur i kultur kak inoslavjanskich $i$ inostrannych. Sbornik dokladov. Belgrad: Slavisticheskoje obshchestvo Serbii, 118-123

Gómez Capuz, Juan (1997): "Towards a typological classification of linguistic borrowing (illustrated by Anglicisms in Romance Languages)". Revista Alicantina de Estudios Ingleses, 10: 81-94. doi: 10.14198/raei.1997.10.08. [Accessed 25 October 2017]

Haspelmath, Martin, and Uri Tadmor (2009): "The loanword typology project and the world loanword database". In M. Haspelmath and U. Tadmor, eds., Loanwords in the World's Languages: A Comparative Handbook. Berlin: de Gruyter, 1-34.

Haspelmath, Martin (2009): "Lexical borrowing: Concepts and issues". In M. Haspelmath and U. Tadmor, eds., Loanwords in the World's Languages: AComparative Handbook. Berlin: de Gruyter, 35-54. 
Haugen, Einar (1950): “The analysis of linguistic borrowing”. Language, 26(2): 210-231.

Hyman, Larry (1970): "The role of borrowings in the justification of phonological grammars".

Studies in African Linguistics, 1(1): 1-48.

Karaulov, Yury, ed. (1998): Russkyi yazyk: entsiklopedia. $2^{\text {nd }}$ ed., Moscow: Drofa.

Kimyagarova, Roza (1968): "Tipy i vidy adaptatsii zaimstvovannoi leksiki v russkom yazyke novogo vremeni (XVII-XX vv.)". Vestnik Moskovskogo Universiteta. Seriya 9. Filologiya, 6: 69-78.

Komlev, Nikolai (2006): Slovar' inostrannyh slov. Moscow: EKSMO-Press.

Kotelova, Nadezhda, ed. (1984): Novye slova i znacheniya. Slovar'-spravochnik po materialam pressy i literatury 70-h godov. Moscow: Russkiy yazyk.

Krysin, Leonid (1975): "Stupeni morfemnoi chlenimosti inoyazychnyh slov". In E. Zemskaya, ed., Razvitie sovremennogo russkogo yazyka. Slovoobrazovanie. Chlenimost' slova. Moscow: Prosveshchenie, 227-231.

Matiello, Elisa. (2013): Extra-Grammatical Morphology in English. Abbreviations, Blends, Reduplicatives and Related Phenomena. Berlin: Mouton De Gruyter.

Matras, Yaron, and Jeanette Sakel (2007): "Investigating the mechanisms of pattern replication in language convergence". Studies in Language, 31(4): 829-865.

Nagano, Akiko, and Masaharu Shimada (2016): "Language contact between English and Japanese and the borrowing of left-headed nominal modification construction". ESSE 2016: Book of Abstracts: 51. www.esse2016.org/downloads/abstracts.pdf

Panov, M. V. (1999): Pozicionnaja morfologija russkogo jazyka. Moscow: Nauka, 1999.

"Parking”. n.d. In Oxford Dictionaries, en.oxforddictionaries.com/definition/parking.

Picone, Michael D. (1996): Anglicisms, neologisms and dynamic French. Amsterdam / Philadelphia: John Benjamins Publishing Company.

Rey, Alain (1995): Essays on Terminology. Amsterdam/Philadelphia: John Benjamins Publishing Company.

Rochtchina, Julia (2012): "Morphology and lexicology interface. Latest Russian neologisms: The next step towards analytism?" In V. Makarova, ed., Russian Language Studies in North America: New Perspectives from Theoretical and Applied Linguistics. London, New York: Anthem Press, 71-84.

Russian National Corpus. N.p., n.d. Available at ruscorpora.ru/

Ryazanova-Clarke, Larissa, and Terence Wade (1999): The Russian Language Today. New York: Routledge.

Shvedova, Yelena, ed. (1980): Russkaya grammatika, vol.1. Moscow: Nauka.

Štekauer, Pavol, et al. (2008): Universals, Tendencies and Typology in Word-Formation: A Cross-Linguistic Study. Josef Šafárik University.

Sztencel, Magdalena (2009): "Boundaries crossed: The influence of English on modern Polish". E-Pisteme, 2(1): 3-17.

Thomason, Sarah Grey, and Terrence Kaufman (1988): Language Contact, Creolization and Genetic Linguistics. Berkeley: University of California Press.

Tikhonov, Alexandr, ed. (2014): Entsiklopedicheskyi slovar'-spravochnik lingvisticheskih terminov i ponyatyi: Russkyi yazyk, T.1. $2^{\text {nd }}$ ed., Moscow: Flinta.

Townsend, Charles (1968): Russian Word-formation. New York: McGraw Hill.

Vaganova, Natalya. (2005): Sovremennye zaimstvovaniya iz anglyiskogo yazyka: Semantikoslovoobrazovatelnyi aspekt: Na materiale anglitsizmov kontsa XX-nachala XXI v. $v$ sovremennom russkom yazyke. $\mathrm{PhD}$ dissertation, Nizhegorodskyi Gosudarstvennyi Universitet. 
Vendina, Tatyana (1999): "Yazykovoe soznanie i metody ego issledovaniya." Vestnik $M G U$. Ser. 19. Lingvistika i mezhkul'turnaya kommunikatsiya, 4: 15-31.

Volodarskaya, Emma (2002): "Zaimstvovanie kak otrazhenie russko-anglyiskih kontaktov". Voprosy yazykoznaniya, 4: 96-118. 